\title{
A CONSTITUIÇÃO HISTÓRICA DA RACIONALIDADE ECOLÓGICAE OS PROBLEMAS AMBIENTAIS NA CONTEMPORANEIDADE ${ }^{1}$
}

\author{
THE HISTORICAL CONSTITUTION OF ECOLOGICAL RATIONALITY \\ AND ENVIRONMENTAL PROBLEMS IN CONTEMPORANITY
}

\author{
Danielle de Ouro Mamed ${ }^{2}$ \\ Jairo Marchesan ${ }^{3}$
}

Sandro Luiz Bazzanella ${ }^{4}$

\begin{abstract}
RESUMO: O presente trabalho busca trazer elementos históricos necessários à compreensáo da racionalidade desenvolvida em torno da gestáo dos bens naturais na contemporaneidade. Para tal, parte-se da análise de como a percepçâo das relaçôes entre ser humano e natureza foi sendo modificada ao longo da história, culminando nos atuais modos de observar e reagir diante dos problemas ambientais atuais, especialmente por meio da instituiçâo de políticas públicas. Assim, parte-se da análise de como o ser humano compreendia a natureza desde a Antiguidade (especialmente na Grécia), passando pelas visōes predominantes na Idade Média, até chegar à Modernidade. A visitaçăo histórica das concepçôes em cada período histórico, mostra-se uma ferramenta importante para compreender as bases, abrangências e limites da açăo humana diante da natureza, sendo esta, portanto, uma ferramenta interessante para que seja possível avaliar os motivos do fracasso das políticas ambientais na contemporaneidade.
\end{abstract}

PALAVRAS-CHAVE: Racionalidade ecológica; crise ambiental; história ambiental; políticas públicas.

ABSTRACT: The present article brings historical elements necessary to understand the rationality developed around the management of natural resources in contemporary times. To attend this intent, it is based on the analysis of how the perception of the relations between human and nature has been modified throughout history, culminating in the current ways of observing and reacting to current environmental problems, especially in the institution of public policies. For this, it starts from the

1 Esta pesquisa é parte integrante do Estágio Pós-Doutoral da primeira autora, no âmbito do Programa de Mestrado em Desenvolvimento Regional, na Universidade do Contestado.

2 Advogada. Doutora em Direito Econômico e Socioambiental (PUCPR). Mestre em Direito Ambiental (UEA-AM). Professora em estágio pós-doutoral na Universidade do Contestado (UnC), com bolsa CAPES - Programa de Mestrado em Desenvolvimento Regional. Santa Catarina. Brasil. mamed.danielle@gmail. com.

3 Doutor em Geografia, professor do Programa de Mestrado em Desenvolvimento Regional da Universidade do Contestado (UnC). Santa Catarina. Brasil. jairo@unc.b

4 Filósofo. Doutor em Ciências Humanas, professor do Programa de Mestrado em Desenvolvimento Regional da Universidade do Contestado (UnC). Santa Catarina. Brasil. sandro@unc.br 
analysis of how the human being understood the nature from the Antiquity (especially in Greece), passing through the prevailing visions in the Average Age, until arriving at the Modernity. The historical visitation of conceptions in each historical period is an important tool to understand the bases, dimension and limits of human action in the face of nature, which is therefore an interesting tool for assessing the reasons for the failure of policies environmental issues in contemporary times.

KEYWORDS: Ecological rationality; Environmental crisis; Environmental history; public policies.

\section{INTRODUÇÃO}

Compreender as relaçôes da sociedade humana entre si, com os bens naturais e os problemas ambientais ${ }^{5}$ advindos de tais processos demanda um esforço teórico no sentido de vislumbrar as raízes que fundamentam sua articulaçăo conceitual e discursiva. Da antiguidade até a contemporaneidade, notadamente, foram construídos e modificados os discursos sobre as relaçóes entre sociedade e natureza, culminando no pensamento ecológico atual diante da crise ambiental inegável em que se insere a vida em totalidade.

Para compreender o tema proposto é necessário, a priori, assimilar, ainda que em sentido abrangente: a compreensâo da natureza (physis) na antiguidade; a visăo da sociedade sobre ela na Idade Média; as transformaçôes proporcionadas pelo pensamento moderno e, finalmente, a conformação do pensamento e/ou racionalidade ecológica atual, perscrutando suas influências, alcances e limites. Apesar de estarmos cientes da complexidade da questăo, reputa-se importante o esforço teórico em estabelecer tais questóes, no sentido de compreender a raiz dos paradigmas que regem o pensamento ecológico operacionalizado nas sociedades atuais, no contexto de uma construçấo hegemônica do conhecimento, afinal: "a História nos permite perceber os interesses inscritos a partir da intervençâo humana num determinado espaço, bem como as transformaçôes nele operadas no decorrer do processo de colonizaçấo e desenvolvimento de um modelo econômico" (MARCHESAN, 2003, p. 11). Como será possível observar, significativa parcela da preocupaçăo atual com a natureza refere-se à sua estreita vinculaçáo com a economia e com os discursos oficiais e oficiosos de desenvolvimento, além de suas concepçôes, bem como as práticas operacionalizadas para execuçâo desta lógica. Tal situaçấo implica uma série de desafios que se colocam para a sociedade, pois diante do cenário problemático ambiental contemporâneo, há que se pensar alternativas para a gestăo dos recursos naturais.

Deste modo, reputou-se útil e necessário observar de que maneira o pensamento na antiguidade, no período medieval e na modernidade incide nas relaçóes entre sociedades e natureza hodiernamente, identificando-se os alcances e limites de cada posicionamento na sociedade atual e no corrente pensamento ecológico. A partir da compreensāo do histórico da relaçăo entre ambiente e sociedade, é possível apresentar variáveis analíticas sobre as formas a partir das quais se tem conduzido as políticas

A ideia adotada no que se refere aos problemas ambientais remete à crise do meio ambiente, entendida como a escassez de recursos naturais e as diversas catástrofes planetárias, surgidas a partir das açôes degradantes do ser humano sobre a natureza (CARVALHO, 2000, p. 202). 
públicas ambientais. A presente pesquisa utilizou-se de método dedutivo, adotando-se o procedimento monográfico e a pesquisa bibliográfica para lograr o objetivo proposto.

\section{COMPREENSÃO DA NATUREZA E QUESTÃO AMBIENTAL NA ANTIGUIDADE}

Ao contrário do que possa parecer à primeira vista, a questăo ambiental, entendida hegemonicamente como o comprometimento da disponibilidade de bens naturais para a sociedade humana, năo é uma preocupaçăo contemporânea. Desde tempos remotos, a partir do momento em que o ser humano passou a registrar em escritos suas relaçóes e reflexóes a respeito de sua vida e existência, tais preocupaçóes săo percebidas. A grosso modo é possível pensar as inquietaçōes diante da natureza neste período em dois grandes grupos: as de ordem filosófica e as de ordem prática.

As preocupaçōes de ordem filosófica correspondem àquelas oriundas da perspectiva e anseio humanos por respostas às suas condiçóes existenciais, como por exemplo, aquelas vinculadas à origem e destino da natureza. Glacken apud Pádua (2010, p. 83) em estudo sobre as diferentes concepçóes intelectuais a respeito da natureza que aparecem na história, chegam a afirmar que da Antiguidade Clássica até o Século XVIII todos os pensadores enfrentaram o tema com base em três perguntas centrais: a) existe um sentido e um propósito na natureza?; b) a natureza possui influência sobre a vida humana e c) a realidade da Terra, em sua condiçăo primordial, teria sido modificada pela açáo do ser humano? Para Pádua (2010, p. 83) tais indagaçôes também visavam um esforço em compreender de que maneira a natureza incidia e influenciava na vida humana, năo havendo até entăo a preocupaçăo em modificar a natureza (o que será observado com maior intensidade a partir da modernidade).

No que tange à sua compreensăo na antiguidade, destaca-se a noçăo de physis grega. Segundo Koike (1999, p. 167), esta ideia é apresentada em tempos atuais como algo equivalente à natureza, no entanto, năo era exatamente este o sentido atribuído pelos antigos. Consoante ao autor, é possível pensar que a physis grega designava a própria realidade ou manifestaçâo do real, porém numa dimensâo muito mais abrangente, já que contempla aspectos metafísicos como a gênese, a essência, substância e forma das coisas, incluindo componentes psíquicos e espirituais (1999, pp. 167-176). Aristóteles, segundo Bornheim (1998, p. 11), denominou os filósofos pré-socráticos como physikoi, ou físicos, o que deve ser interpretado com cautela, já que esta ideia de "física" em nada se assemelha à acepçăo moderna do termo, assim como a physis năo pode ser interpretada apenas como natureza. Segundo o autor, as interpretaçōes metafísicas dos gregos săo peculiares em razáo da ausência de separaçáo entre o mundo divino e o mundo natural, além do fato de que a religiosidade náo excluía certa "ousadia intelectual" por parte dos seres humanos (BORNHEIM, 1998, pp. 9-10).

A ideia de physis, portanto, nesse contexto, consiste em um conceito complexo, cuja compreensâo está vinculada ao entendimento do pensamento pré-socrático. Porém, há alguns aspectos que podem ser elencados para sua melhor compreensâo, como por exemplo a vinculaçấo ao que é manifesto, ao que brota, se abre ou emerge, além do fato de que, para os gregos, a physis năo contrapóe psíquico, ao anímico ou ao espiritual, aspectos também pertencentes à physis (BORNHEIM, 1998, p. 14).

No que se refere às questôes práticas relacionadas à natureza na antiguidade, destaca-se a apreensâo em suprir as necessidades de bens naturais na perspectiva de 
disponibilidade para a humanidade e também os desequilíbrios ambientais observados em determinadas situaçóes.

Para Prado (2002, p. 7) muitos eram os dilemas nas sociedades antigas no que se refere ao ambiente: o acesso à água potável, lixo biológico, desmatamento, erosăo de solos, esgoto e lixo doméstico sáo alguns dos temas que traziam certos desassossegos desde os tempos antigos, que foram sensivelmente aumentadas em decorrência da sedentarizaçăo e aumento populacional humano em determinado espaço. Com esta modificaçáo do modus vivendi das sociedades, foi necessário criar formas de contornar as situaçóes que se colocavam, como por exemplo, a necessidade de armazenamento de água e suprimentos alimentares, além das primeiras regulamentaçôes sobre tais questóes. Consoante aos estudos de Prado (2002, p. 8), existem documentos do povo sumério, datados de 4.000 a.C. que contém instruçôes para a irrigaçâo de lavouras visando o bom aproveitamento das águas, além de diversos relatos sobre a realizaçâo de obras de armazenamento e distribuiçăo dos bens naturais em diversos lugares no contexto da antiguidade.

As preocupaçóes com a gestăo dos bens naturais, principalmente para satisfaçăo das necessidades humanas, no entanto, năo eram a única faceta da questăo ambiental possível de serem encontradas na antiguidade. A crise e o colapso civilizacional por conta de desequilíbrios ambientais também aparecem em alguns relatos como em Diamond (2006), que demonstra o declínio da civilizaçáo maia, ${ }^{6}$ que sofreu efeitos de uma combinaçăo de dano ambiental, crescimento populacional e mudança climática, denotando que os desastres ocasionados pela má gestăo ambiental năo constituem uma ameaça exclusivamente moderna ou contemporânea. De igual modo, as experiências que denotam a ocorrência de desastres ambientais constituem, a princípio, as primeiras situaçôes documentadas da humanidade no sentido de chamar a atençâo para o caráter finito dos bens naturais necessários à sobrevivência humana.

Portanto, a antiguidade, notadamente, trouxe alguns aportes importantes à compreensăo dos fenômenos naturais, tanto pelas reflexóes filosóficas acerca da origem da natureza, quanto pelas experiências que apontavam para a necessidade de utilizarse dos recursos naturais de forma a náo inviabilizar este uso no futuro. Ao estudar e analisar o pensamento observado neste período, nota-se a consideraçăo da natureza como parte da existência humana, nâo havendo, naquele momento, concepçôes de separaçấo entre sociedades e natureza. Pelo contrário, buscava-se compreender o meio para verificar de que modo este influenciava na vida social. Estas indagaçóes, especialmente aquelas substanciadas na physis grega, levam a pressupor que naquele momento, o ser humano buscava compreender-se e, consequentemente, compreender o mundo que se circunscrevia como parte indissociável da condiçâo humana e de seu existir com a natureza.

\section{NATUREZA COMO OBRA DA CRIAÇÃO DIVINA NA IDADE MÉDIA}

A concepçáo do ser humano como parte integrante da natureza, predominante na Antiguidade permanecia, de certo modo, no período medieval. Porém, de maneira

6 Avançada sociedade nativa mesoamericana pré-colombiana (DIAMOND, 2006). 
geral, há certa submissáo às condiçôes naturais ao mesmo tempo em que se buscava trabalhá-las para suprir as necessidades humanas. A submissâo se dá em razâo de que a natureza era interpretada como manifestaçáo dos desígnios de um ser superior (Deus). Assim, o esforço em manejá-la é expresso na alusăo às práticas de desenvolvimento da agricultura.

Para Barros (1999) seria incoerente buscar na Idade Média as inquietudes ecológicas que se observam atualmente ou mesmo encontrar efeitos e práticas que de algum modo se assemelhem à açâo destrutiva que os humanos tem imposto e perpetrado sobre a natureza. Os conflitos envolvendo o meio natural, naquele contexto, tinham características e dimensóes diferenciadas. Para o autor, o feudalismo, forma de organizaçăo política, social e econômica predominante na época, constituiu-se num modo de produçấo ecológica, em que o ser humano năo se concebia sem a natureza, dada a sua dependência diante dela.

Na concepçăo medieval de mundo, há, no entanto, um notável predomínio do pensamento teocêntrico, que indicava certa ordem de funcionamento do cosmos: o planeta Terra, de acordo com tal concepçăo constituía-se o centro de tudo e os papéis sociais estavam claramente predeterminados hierarquicamente, havendo uma relaçâo existente entre servos e senhores, entre os senhores e seus superiores feudais, estes e o rei, e entre o rei e o imperador (GIDDENS, 1991, pp. 18-20). Naquele contexto, este modo de existir em sociedade partia da vontade de Deus e, portanto, năo havia previsáo de modificaçōes significativas destes status já pré-estabelecidos. Deste modo, cabia aos seres humanos a aceitaçâo tácita de que aquela era a vontade soberana de um poder superior.

Deste modo, quanto à interpretaçăo intelectual da natureza e sua relaçấo com as sociedades, nota-se o protagonismo do pensamento teocêntrico no período. Nos primeiros séculos da Idade Média, a filosofia de raiz teológica aliada ao pensamento desenvolvido na Antiguidade fornecerá elementos basilares para a interpretaçấo da natureza a ser adotada pelos cristăos. Ou seja, ela é compreendida como obra da criaçăo que contempla em si a totalidade das criaturas (MEIRINHOS e PULIDO, 2011, p. $\mathrm{X})$. Para os autores, a interpretaçăo simbólica da natureza como reflexo do percurso moral ou especulativo da gênese e regresso a Deus pela açâo e o conhecimento pode ser encontrado em textos franciscanos do século XIII (MEIRINHOS e PULIDO, 2011, p. XI). Portanto, pode-se afirmar que as inquietaçōes sobre a gênese e destino da natureza perduram durante o período medieval, apesar de outras preocupaçōes se somarem e tomarem maior destaque.

Para Barros (2000), diferentemente do que ocorreu na modernidade, a noçăo de natureza na Idade Média náo se baseava em saberes técnicos, mas de um pensamento em que o ser humano vivia lutando contra a natureza, ao mesmo tempo em que reconhece que apenas Deus teria o poder de controlá-la. Ademais, pela falta de argumentos técnicos ou científicos, além da inexistência de um Estado protetor, a humanidade deixava a soluçăo de seus dilemas em relaçâo ao mundo natural, nas "mâos divinas". Isto teria ocorrido, a título exemplificativo, quando a peste bubônica assolou a Europa. Diante da inexistência de informaçôes técnicas a respeito, aceitava-se a teoria de que a contaminaçâo era induzida pela cólera de Deus e/ou pela conjunçăo dos planetas (BARROS, 1999). Assim, o embate entre ser humano e natureza já năo dizia respeito somente à hostilidade a ser vencida pelo camponês diante da dureza do trabalho no campo e no 
desenvolvimento da agricultura, mas também se referia à necessidade de harmonizar as desigualdades, os pecados e a violência (BAUAB, 2005, p. 54).

A natureza era vista como parte da vida humana pelo trabalho na terra, sendo suas vicissitudes, no entanto, reflexos da fúria de um Deus insatisfeito com a conduta humana, instituindo o sentimento de culpa cristă. Nesse sentido, há que se ressaltar que os desequilíbrios naturais também aparecem como componente importante para a dominaçăo ideológico-religiosa, característica da época, pautada no temor de uma represália sobrenatural diante da desobediência às normas divinas institucionalizadas pela Igreja.

Portanto, comparando-se a Antiguidade com o Período Medieval, se observa no que concerne à relaçâo do ser humano com a physis, uma mudança paradigmática em que o ser humano portador de uma visáo imanente de mundo natural em que se encontrava integrado passa para uma visâo transcendente de mundo natural. Enquanto na Antiguidade predominou a busca humana por explicaçóes sobre os fenômenos naturais a partir de uma visâo cosmológica, na Idade Média vê-se que tais questionamentos assumem a primazia das explicaçōes teológicas cristăs vinculadas ao catolicismo, submetendo a razăo a serviço da fé, conformando o discurso teológico como intérprete por excelência da verdade revelada, constituída da obra da criaçăo. Esta situaçăo assumiu contornos diferenciados com o advento da modernidade e da retomada do protagonismo da racionalidade humana na percepçâo e compreensâo do mundo natural e social.

A retomada da primazia da razăo sobre a fé, demarcando a afirmaçăo do antropocentrismo como uma das características da modernidade, trouxe outras consequências que benefícios ao desenvolvimento das sociedades humanas, mas que também apresentaram como efeito colateral questóes e problemas a serem enfrentados pelas sociedades. Na modernidade, foi inaugurada uma lógica de pensamento muito peculiar e afeita objetivamente ao desenvolvimento civilizacional por meio de novos arranjos econômicos, científicos, técnicos, produtivos e sociais, intensificando situaçōes e potencializando problemas até entăo desconhecidos ou minimizados na tradiçăo civilizatória ocidental, entre eles a questăo das relaçôes entre sociedades e natureza.

\section{MODERNIDADE E A DOMINAÇÃO DA NATUREZA}

Como já assinalado, a modernidade, como período histórico e como racionalidade, constitui um marco na mudança do pensamento humano. Para compreender as implicaçóes das concepçóes humanas com a natureza, primeiramente, é necessário ponderar que a modernidade nâo nasceu de forma abrupta, mas foi a construçấo e o resultado de uma longa transiçăo de ideias que partiu de intensas mudanças na forma das sociedades desenvolverem a economia: ${ }^{7}$ os fenômenos da acumulaçăo, da divisâo

Há que se esclarecer que a compreensâo de economia adotada inclui toda uma série acontecimentos e mudanças que se iniciam na Alta Idade Média e culminam no mercantilismo, entre elas, os avanços científicos que permitirăo no Renascimento, que atestou a falência da teoria de que a Terra seria o centro do Universo, assim como o aumento populacional, do comércio, das cidades, das técnicas produtivas, arrefecimento do poder da Igreja Católica, Reforma e Contrarreforma e entre outras questôes que culminam na variável econômica com a afirmaçăo do mercantilismo. 
do trabalho, da criaçăo de mercadorias, da moeda e da consolidaçăo da propriedade privada ${ }^{8}$ săo alguns dos elementos presentes nesta transiçáo, que começa a tomar forma com o mercantilismo.

O mercantilismo nâo chega a ser definido como um sistema econômico, mas como um conjunto de doutrinas, marcado pelo conteúdo ético e religioso, além da constante interferência pelos Estados Nacionais recém-formados (FEIJÓ, 2001, p. 59). A partir do mercantilismo, começa-se a perceber uma importante modificaçăo nas estruturas sociais, especialmente no que tange à economia, fornecendo, portanto, o ideário necessário à nascente modernidade.

Como parte das transformaçôes proporcionadas pela transiçâo para a modernidade e pela consolidaçấo do pensamento moderno destaca-se o desenvolvimento das ciências e de novos métodos de análise que vâo modificar, em muito a relaçâo entre humanidade e natureza. Uma das rupturas observadas, nesse sentido, foi o declínio do pensamento predominantemente teocêntrico para a visăo antropocêntrica do universo (VILLORO, 2010, pp. 12-13). Para tanto, foi necessário um resgate da racionalidade como marca distintiva do humano, solapada pelo teocentrismo medieval, fornecendo-lhe, assim, caráter mais individualista. Se antes havia uma pluralidade de atores sociais que conviviam, a modernidade traz a necessidade de constituir a soberania racional do humano, que do ponto de vista político resulta na constituiçáo dos Estados Nacionais como expressáo de uma razáo política, administrativa e jurídica sobre territórios e populaçôes, concentrado num poder soberano (GROSSI, 2003, p. 30). Vê-se, deste modo, a transformaçăo de uma sociedade que comportava diversos segmentos sociais e poderes difusos (caracterizando certo pluralismo) para um modelo de organizaçăo social, política e econômica que tende à homogeneizaçăo, regida pela figura do poder soberano do Estado, centralizador das regras para a vida em sociedade.

O avanço e as transformaçóes da ciência, por sua vez, constituem o principal elemento que vem a modificar o modo pelo qual o ser humano passou a lidar com a natureza. É certo que a saída do aspecto teológico como determinante do fazer científico e uma visăo mais individualista do ser humano em muito contribuíram para esta nova concepçâo. No entanto, outro ponto importante é a fragmentaçâo das ciências trazida pela modernidade, com a pretensăo de lhes conferir objetividade em contraposiçăo às variáveis subjetivas, concentrando o domínio da natureza nas máos de um novo criador, o ser humano.

Nesse sentido, observa-se a influência de autores como Isaac Newton, Galileu Galilei e Copérnico, sendo, no entanto, de grande valia a obra de Renée Descartes, quem contribuiu com a construçăo de uma epistemologia para a ciência, havendo proposto a sistematizaçăo do conhecimento visando uma construçăo mais "segura" para o saber científico. A lógica cartesiana baseia-se no ceticismo metodológico, rechaçando tudo aquilo que năo for passível de comprovaçăo científica (DESCARTES, 1996), propondo a divisáo das ciências em diversas partes e, portanto, retirando o caráter holístico que contemplava as diversas formas de saber existentes até entăo.

8 Tema desenvolvido como parte de tese de doutorado da primeira autora. Para maior apronfundamento, Cf. Mamed, 2016. 
Tal racionalidade, por motivos desta natureza, entre outros, contribuiu para a consolidaçâo de um conhecimento autoafirmado como legítimo, relegando à incredulidade, outras formas de saber desenvolvidas pela humanidade no contexto do mundo antigo e medieval. Ou seja, a modernidade se apresenta com o ímpeto do moderno, do novo, do verdadeiro, demarcando preconceitos em relaçăo ao conhecimento especulativo, lógico e racional constituído nos contextos civilizatórios anteriores. De forma diversa ao que ocorria na Antiguidade, o conhecimento passou a ser construído sem considerar, por exemplo, a condiçăo imanente de mundo e da totalidade da physis no seu aspecto teleológico em que se circunscrevia a vida em sua totalidade. Ou seja, a vida humana representava uma condiçâo vital entre outras, presentes na physis, havendo ainda muitos aspectos a serem considerados. Tais aspectos, no entanto, por năo comportarem comprovaçâo pelos métodos propostos pela ciência, acabaram sendo desconsiderados, promovendo uma transiçấo de percepçăo e concepçăo do humano em relaçăo à natureza e ao mundo.

Considerando este novo modo de observar a natureza, Prigonine e Stengers (1991, p. 1) concluem que o ser humano acaba se tornando um estranho ao mundo que descreve. Este processo está relacionado diretamente ao desenvolvimento das ciências, que assume a perspectiva de compreensâo para modificaçấo da natureza (1991, p. 2). A partir da modernidade, fica latente a ideia nuclear de que as ciências devem servir à construçâo de um conhecimento hegemônico voltado à dominaçấo e modificaçāo da natureza. Esta premissa é bem expressa nas representaçôes artísticas do período renascentista, nas quais se observa um destaque aos olhos e às máos, como em Leonardo da Vinci (1947, p. 31), que explica a alusâo ao olho em razâo de que é ele quem vislumbra os novos rumos a seguir (conhecimento sobre o mundo) e ordena às máos em que sentido estas devem agir para criar (e modificar a natureza). O conjunto do intelecto com a possibilidade de criar do ser humano também é enaltecido por Francis Bacon (1999, p. 33) ${ }^{9}$ quando pondera que nem a măo humana nem o intelecto, considerados separadamente, podem lograr muitos feitos: "todos os efeitos se cumprem como instrumentos e recursos auxiliares, de que dependem, em igual medida, tanto o intelecto quanto as măos". Deste modo, à constituiçăo da ciência moderna é inerente o desvanecimento do interesse pelos fenômenos imutáveis ou estáveis, para dar lugar ao debate diante das evoluçōes, crises e instabilidades (PRIGONINE e STENGERS, 1991, p. 4). Ou seja, a simples compreensâo do mundo para geraçăo de conhecimento dá lugar à construçăo de um pensamento com a finalidade explícita de modificar a natureza conforme os interesses das sociedades. Exemplo desse pensamento da natureza como substrato para realizaçóes humanas pode ser também encontrado em Bacon, que defendia o Estado como uma instituiçăo científica, destinada ao domínio da natureza para melhorar a sorte do gênero humano (BACON, 1999).

Imbuída desta aparente motivaçăo propagada como pressuposto no tempo presente (melhorar a vida e a qualidade de vida humana), a sociedade moderna

9 Trata-se de uma concepçấo da organicidade ou corporiedade. Tal ideia compara a organizaçăo social, política e econômica da sociedade como se constituíssem um corpo humano, sendo que cada órgâo tem uma funçâo específica, uns mais importantes que outros, ou de modo que um órgáo específico, determina como o outro deve funcionar. 
passou a empreender um ousado projeto que marcou definitivamente a modernidade: a Revoluçăo Técnico-Científica. De acordo com Santos (1983, p. 14) o desenvolvimento tecnológico da humanidade começou muito antes do capitalismo, entretanto, seu ritmo era lento e nâo se observava um conhecimento sistematizado que lhe fornecesse sustentaçăo. É justamente o advento do capitalismo que demanda das sociedades este conhecimento (que foi suprido pela ciência) visando, entăo, "aplicar os conhecimentos científicos e tecnológicos à produçăo e aos processos produtivos" (SANTOS, 1983, p. 16). Deste modo, a Revoluçăo Industrial, subsidiada pelo progresso científico e tecnológico, respondeu aos anseios de aumento da eficiência pela maquinofatura, porém, trazendo consequências visíveis para a natureza mesmo naquela época de 'euforia' industrial.

Foram fundamentalmente modificadas as formas pelas quais as sociedades produziam, bem como os seus padróes de consumo. ${ }^{10}$ Se antes, a capacidade de produçấo era limitada à manufatura, a partir da Revoluçấo Industrial, com o advento da produçâo em massa pela maquinofatura, tornou-se necessário que as pessoas consumissem mais do que estavam habituadas, a fim de que houvesse demanda para todos os produtos e serviços nascentes. Como consequência, desenvolveu-se um visível incremento no uso de matéria prima (recursos naturais) e também consequente aumento nos resíduos gerados.

O`Connor, nesse sentido, demonstra que mesmo nos tempos de apogeu do nascimento do modo de produçâo industrial, os efeitos para o meio ambiente já eram visíveis. Năo foi necessário esperar muito tempo para que as consequências pudessem ser percebidas: a cidade inglesa de Lancashire aumentou sua produçâo de carvấo vertiginosamente para dar conta das demandas industriais. Como resultado, a cidade experimentou uma massiva contaminaçăo atmosférica, afetando a saúde de seus habitantes e reduzindo, em muito, espécies vegetais (O 'CONNOR, 2002, p. 25). Até mesmo Engels (1975, p. 76) relatou quadros de condiçôes insalubres em que viviam os trabalhadores na Inglaterra, especialmente no que se refere à poluiçăo atmosférica, urbanizaçâo precária e a consequente presença de lixo pelas ruas. Assim, ainda que a mais propagada discussăo sobre crise ambiental venha sendo desenvolvida atualmente, nota-se que desde o início da mudança em termos de modo de produçăo, os sinais de desequilíbrio ambiental já eram latentes.

Todas essas mudanças no seio da sociedade, também sâo sentidas fortemente pelo ser humano. Bazzanella (2010, p. 89), chama atençăo para a mudança observada neste período, defendendo que uma das principais transcendências da modernidade se refere à primazia que a economia passa a exercer em relaçăo à vida e à forma da existência humana: "Assim, tornou-se quase unânime a opiniăo de que é por meio da economia que se pode alcançar a felicidade". De acordo com o autor:

ao elevar a racionalidade gestora da economia à condiçăo primeira da existência humana, a seu substrato ontológico, a modernidade opera uma ruptura com a concepçăo de economia presente nos primórdios ocidentais da Grécia Antiga. Ou seja, a modernidade inverte as relaçôes entre política e economia, subordinando a esfera da política à esfera da gestáo econômica do mundo, da vida, assim como subordina a vida pública à vida privada. (BAZZANELLA, 2010, p. 89)

10 Como produçấo entende-se os processos pelos quais os produtos sâo elaborados e os serviços sâo prestados. Já o consumo consiste no ato de uso dos recursos naturais, bens e serviços, tanto pelos indivíduos quanto pelas instituiçōes (TERRY e ÓRUE, 2013, pp. 157-158). 
Ou seja, se antes a economia desempenhava o papel de mantenedora das necessidades de subsistência humana, agora passa a ocupar sua própria razăo de existência. De certo modo, este processo também é demonstrado por Sen (1999), para quem a economia 'logística' (meios de prover as necessidades) suplanta sua própria finalidade, que é o atendimento das necessidades humanas. Para o autor, o meio se tornou mais importante do que o fim.

Deste modo, há que se reconhecer que a concepçâo utilitarista da natureza a partir da modernidade representa uma ruptura com o pensamento Grego Antigo e sua concepçâo vital circunscrita ao âmbito da physis que incluía a totalidade da existência em suas análises, o que de certo modo acontecia também no pensamento medieval, uma vez que se observavam os possíveis aspectos metafísicos que pudessem estar envolvidos nos fenômenos naturais. Tal desligamento é refletido de forma patente, na racionalidade ecológica atual, o que fica demonstrado mesmo nas concepçōes de desenvolvimento sustentável, cujo ideário busca vincular o cuidado com o meio ambiente às necessidades sociais e aos interesses econômicos (conforme será observado adiante), com um acentuado predomínio dos interesses econômicos frente à preservaçáo da natureza. Deste modo, uma concepçâo holística, ${ }^{11}$ de certa maneira, continua afastada do pensamento ecológico vigente na atualidade, apesar de ser possível encontrar algumas tentativas de resgatar esta visâo diferenciada da relaçăo entre sociedades e natureza.

A modernidade, por um lado, resgatou a primazia da razăo, conformando o pensamento humano e permitiu que este retomasse o controle do próprio destino. No entanto, como contrapartida, foram geradas consequências indesejáveis advindas desta liberdade de pensamento. O ser humano, em seu afă de independência, acabou por desvincular-se da natureza, que lhe fornece o substrato para a própria vida, ocasionando uma crise profunda nos âmbitos social, político, econômico e ambiental, e afetando desde o senso de pertencimento do elemento humano ao mundo, até mesmo ao suprimento de suas necessidades.

O modo capitalista de produçâo, apesar de haver facilitado algumas as condiçôes da vida humana por um lado, em suas diversas fases trouxe em seu bojo desigualdade social abissal, fomentando a pobreza, a violência social e o depauperamento das condiçôes materiais e naturais de existência humana. As melhorias atribuídas a este sistema, no geral, săo identificadas, por exemplo, como o incremento do conhecimento sobre a saúde humana pelo desenvolvimento de tecnologias de medicamentos, vacinas, padróes de assepsia e outros (melhorias sanitárias), a possibilidade de transportar-se com maior velocidade e eficiência, o acesso à funcionalidades como novas tecnologias de comunicaçăo, energia elétrica, abastecimento hídrico e etc. Por outro lado, para tornar isto possível, a modernidade e o capitalismo precisaram apoiar-se no despojo de terras dos mais pobres, na exploraçăo desumana do trabalho, no grande lucro em favor dos proprietários em detrimento da miséria dos trabalhadores e, finalmente, na criaçăo de uma estrutura social excludente e permeada dos mais diversos infortúnios à humanidade. Este afastamento, notadamente, inclui a substituiçâo das formas diretas do ser humano de lidar com o meio natural pelos produtos e serviços proporcionados

11 Como concepçáo holística, entenda-se a consideraçăo da realidade em funçâo de totalidades integradas cujas propriedades nâo săo passíveis de ser reduzidas a unidades menores (CAPRA, 1996). 
por esta nova era tecnológica.

Vê-se que, desde a antiguidade até a consolidaçăo da modernidade, perderam-se gradativamente as relaçôes de pertencimento das sociedades em relaçâo à natureza, o que potencializou a constante pressáo para a homogeneização da sociedade através do fenômeno da globalizaçâo cultural e também das formas de produzir. Por esta via, preconizou-se e implementou-se um modelo de sociedade pautado em padróes externos, desconsiderando as diferenças culturais e deixando as sociedades cada vez mais parecidas ao modelo de economia financeira globalizada proposto pelo capitalismo. Nesse sentido, nota-se uma constante pressăo do poder econômico para solapar qualquer modo de vida que náo caiba nos moldes das sociedades modernas, pensadas para compor uma hegemonia de pretensóes globais: povos indígenas, comunidades tradicionais, ciganos, faixinalenses, caiçaras ${ }^{12}$ e todas as demais categorias de sociedades năo-hegemônicas sâo pressionadas a serem integradas ao modo de vida "moderno" ou a compor as redes mercadológicas. Normalmente, sâo essas as sociedades que ainda resistem em manter uma vinculaçăo mais estreita com o ambiente natural, considerando-o como parte de seu existir. Porém, quando este senso de pertencimento inviabiliza o desenvolvimento da economia, busca-se tornar impossível a estes povos o exercício de seu modo de vida.

Desde o advento da modernidade até o pensamento ecológico na atualidade, observa-se um constante aprofundamento da importância dos mercados na regulaçáo da vida em todos os seus aspectos. Como será possível observar, atualmente, o viés mercadológico de organizaçâo social tem sido a tônica dos discursos e práticas cotidianas. Este processo, consequentemente, contratualizou e mercantilizou elementos naturais que deveriam ser considerados direitos inalienáveis dos seres humanos.

A partir do posicionamento filosófico acerca do pertencimento do ser humano ao mundo, convive-se na atualidade com uma tendência de afastamento da humanidade com a natureza para que esta possa constituir-se em objeto, pronto a servir aos seus desígnios, ignorando-se os nefastos efeitos dessas açôes à própria qualidade da vida humana. Na análise da questăo do pensamento ecológico atual, será possível observar a aparente preocupaçáo com a questăo ambiental, porém, ao longo do processo, se observa o retorno às prioridades econômicas, apesar de todos os sinais de esgotamento dos bens naturais e do modelo econômico em curso.

\section{RESGATANDO QUESTÕES HISTÓRICAS PARA COMPREENDER 0 PENSAMENTO ECOLÓGICO NA CONTEMPORANEIDADE}

Segundo a proposta do presente texto, pode-se distinguir a relaçăo entre humanidade e natureza a partir de ideias centrais encontradas nos distintos períodos históricos: a) na antiguidade, a preocupaçăo com o suprimento das necessidades das sociedades, o enfrentamento de crises ambientais e também a necessidade de conhecimento sobre a gênese e destino da physis constituem os principais temas abordados;

\footnotetext{
12 Em termos ambientais, a observaçâo do modo de vida dos povos indígenas e comunidades tradicionais é interessante, uma vez que, pelo seu modo de vida diferenciado, implicam um baixo impacto ao meio ambiente (CUNHA, 2010).
} 
b) na Idade Média, o ser humano em suas condiçóes existenciais, se vê dependente dos ciclos naturais sob uma forte influência do pensamento teocêntrico característico deste período, de modo que ao ser humano, sofrer as intempéries ambientais significava submeter-se à vontade divina e, finalmente, c) com o advento da modernidade, esta condiçăo é transformada em razăo do desenvolvimento da economia, da organizaçăo estatal e também das ciências, objetivando a natureza e proporcionando ao ser humano o poder de modificá-la.

Talvez se possa partir do pressuposto de que a racionalidade ecológica na contemporaneidade possui características peculiares. Porém, há que se considerar que também é fruto da mudança de pensamento, cujas fases năo sâo sobrepostas, mas aparecem com maior ou menor força ao longo do tempo. Atualmente, veem-se diversos embates no campo ambiental envolvendo concepçôes utilitaristas dos bens naturais ou, em outros casos, concepçôes holísticas, que consideram a natureza e o ser humano como parte integrante de um mesmo sistema.

Ao mesmo tempo em que a revoluçăo técnico-científica trouxe para as sociedades benefícios e avanços em termos de facilidades e funcionalidades da vida cotidiana, também ocasionou malefícios e riscos advindos dessa nova forma de produzir, distribuir e consumir (industrial) que foram sendo incorporados à sociedade como "males necessários" ao "progresso" e ao "desenvolvimento". Beck denomina a conformaçâo desta sociedade como 'sociedade de risco', que corresponde àquela caracterizada pela crise ambiental resultante das transformaçóes da primeira modernidade (industrial). Segundo o autor, a segunda modernidade (ou modernidade avançada) seria o estágio atual da modernidade que carrega os danos e os riscos decorrentes do novo modelo civilizacional adotado (BECK, 2000). A ocorrência de danos concretos e a possibilidade de riscos, portanto, constituem claramente o que se tem compreendido atualmente como crise ambiental, ou, em perspectiva mais abrangente, crise socioambiental, uma vez que náo é possível desvincular as sociedades deste processo.

Năo obstante seja possível observar a abordagem dos problemas ambientais em períodos anteriores, é patente que houve um vertiginoso aumento tanto em quantidade quando em gravidade de danos ambientais a partir de meados do século XX, havendo uma intensificaçăo persistente até os dias atuais.

A ideologia que fundamentou o modo de conduzir a economia a partir da modernidade, o liberalismo, também contribuiu para as inegáveis consequências ambientais. O modelo liberal, por partir da crítica ao intervencionismo do Estado na economia, defende que o próprio mercado deve regular a si mesmo, sem subsídios estatais, reservas de mercado, protecionismos ou quaisquer outras interferências (STEWART JUNIOR, 1995, pp. 73-74). Assim, sem nenhum óbice aos seus interesses, as regras de mercado poderiam controlar o atendimento das necessidades humanas. O problema, no entanto, consiste em que, segundo as premissas do capitalismo, o lucro é a grande finalidade, nâo sendo observadas com maior atençâo as necessidades reais e os interesses das sociedades: prevalece a busca pela maior vantagem para o sistema econômico, náo refletindo em ganhos reais à sociedade.

Após a ameaça e constrangimentos com que o capitalismo se deparou a partir das experiências socialistas, sobretudo de matriz soviética, a partir de 1980 propagouse uma nova leitura que viria a ser implementada nos países: o neoliberalismo. Seu 
defensor, Hayek (1990), pugnava, entăo, o resgate da ideia de Estado Mínimo, onde prevaleceria a livre concorrência. Para Costa (2008, p. 12) a retomada e reforma do discurso liberal sob a forma neo foi necessária devido à falta de ideologia para o mundo globalizado de que necessitava o capital, optando-se por resgatar a ideia liberal, construída no século XVIII, adaptando-a às exigências atuais. Năo obstante, segundo o autor, fazendo-se um balanço dos efeitos do neoliberalismo, observa-se que este deixou de saldo desastres econômicos, sociais, políticos e ecológicos, pois:

Em todos os países em que foi implantado, ocorreu a concentrac, ăo de renda e aumento da pobreza; o mundo se tornou mais instável e as crises econo^micas, sociais e políticas, mais constantes, os trabalhadores perderam direitos e garantias conquistadas há séculos, precarizou-se o trabalho e reduziram-se os salários. Só o grande capital, e os especuladores em especial, podem comemorar o advento do neoliberalismo. (COSTA, 2008, p. 13)

Cabe pontuar, no entanto, que o neoliberalismo se apresenta como face mais recente de um fenômeno mais antigo: a mercantilizaçấo e financeirizaçăo da vida em todas as suas instâncias, o que começou a ser delineado a partir da modernidade e do próprio sistema econômico vigente. Isto porque, segundo a lógica neoliberal, o mercado é capaz de regular todas as relaçôes sociais que envolvem a economia, o que inclui as políticas que definirâo o uso dos recursos. Na sequência de tantas diretrizes político-econômicas voltadas ao crescimento da economia de forma desvinculada das questôes sociais e ambientais (já que se preconizou o interesse dos mercados), teve-se como resultado latente crise ambiental. Segundo Gonçalves (2016), tal crise se traduz em desequilíbrios visíveis como desmatamento, erosăo e desertificaçăo de solos, mudanças climáticas, crise energética, crise nos alimentos, crise migratória, urbanizaçăo desenfreada, crise política, crise sanitária, crise militar e, finalmente, crise econômica. De acordo com o autor, tais crises remetem uma crise civilizatória de múltiplas dimensóes (GONÇALVES, 2016).

Apesar de haver um senso comum disseminado de que somente atualmente a questâo ambiental tem alcançado maior destaque nos âmbitos de discussăo, os problemas ambientais assumiram destaque na agenda internacional desde meados do século XX, em diversas convençōes internacionais, até a atualidade. Nesses espaços, buscava-se chamar a atençăo quanto ao tema e articular esforços possíveis em termos globais ou planetários. Em especial, destacam-se as convençôes realizadas pela Organizaçáo das Naçôes Unidas (ONU), que capitaneou a discussăo no campo internacional e exerceu considerável influência na formulaçăo de legislaçâo e políticas públicas nos países diretamente envolvidos nos debates sobre as questóes climáticas e ambientais.

Pode-se dizer, desta forma, que parte da racionalidade ecológica atual, bem como das medidas pensadas para a soluçáo de seus problemas estâo relacionadas às discussōes desenvolvidas nessas instâncias. É a partir dessas conferências que foram estabelecidos os parâmetros que nortearam as políticas ambientais a serem adotadas pelos governos, a exemplo da necessidade de pôr limites do crescimento (Conferência de Estocolmo, 1972); a proposiçấo do conceito de desenvolvimento sustentável voltada à equidade intergeracional (Relatório Brundtland, 1978); a visâo de sustentabilidade como equilíbrio entre o econômico, o social e o ambiental (Rio 92 e Conferência de Joannesburgo, 2002) e, atualmente, a ideia de economia verde proposta pela Rio+20 (2012). 
A primeira conferência internacionalmente relevante acerca da questáo ambiental foi a Conferência de Estocolmo e que resultou no documento denominado Declaraçăo das Naçôes Unidas sobre Meio Ambiente Humano. O enfoque do texto resultante da referida conferência apontou para o desgaste do meio natural frente ao desenvolvimento econômico pretendido pelos países: a proposta era frear o crescimento dos países e, consequentemente, diminuir a degradaçáo ambiental. Na ocasiăo, as pretensôes desenvolvimentistas foram questionadas, o que gerou certo desconforto entre os países: se os mais desenvolvidos colaboraram em maior medida para o diagnóstico ambiental negativo devido sua atividade poluidora, os países menos desenvolvidos argumentavam que náo poderiam ser penalizados em suas pretensóes de incrementar sua economia, já que contribuíram em menor grau para este quadro (BURSZTYN e PERSEGONA, 2008, pp. 150-151). Questionaram-se os efeitos da reduçăo de poluiçăo decorrente de atividades econômicas para os países mais pobres. Assim, a tônica do discurso naquele momento, foi a questâo do desenvolvimento e sua influência sobre a qualidade do meio ambiente.

Como alternativa, buscou-se a implementaçăo do termo ecodesenvolvimento, proposto durante a reuniâo do Conselho Administrativo do Programa das Naçôes Unidas sobre Meio Ambiente, em 1973, por Maurice Strong. A ideia era solucionar a questáo do desenvolvimento, adaptando-o às necessidades das áreas rurais dos países menos desenvolvidos valorizando os conhecimentos locais com respeito ao meio ambiente (SILVA, 2009, p. 102).

No entanto, mais dez anos após a Conferência de Estocolmo, verificou-se que os esforços empreendidos estavam abaixo do que seria necessário para que alguma mudança pudesse ser vislumbrada. Assim, foi criada a Comissăo Mundial sobre Meio Ambiente e Desenvolvimento, que elaborou e publicou o relatório "Nosso Futuro Comum", também conhecido como Relatório Brundtland. Foi este documento que plasmou a ideia de desenvolvimento sustentável como aquele que atende às necessidades das geraçóes presentes, sem afetar o mesmo direito das geraçóes futuras. Trata-se, portanto, de uma perspectiva de equidade intergeracional.

Após anos de discussôes nos fóruns internacionais e mesmo diante do comprometimento dos países em promover políticas públicas de proteçăo ambiental, năo é observada uma real efetividade em termos de melhora da crise ambiental instalada. Deste modo, a Conferência das Naçóes Unidas sobre Meio Ambiente e Desenvolvimento (Cúpula da Terra, Rio 92 ou Eco 92), buscou avaliar os avanços desde 1972 e promover medidas como a adoçáo de tecnologias menos poluentes e estabelecer cooperaçáo internacional para o tema. Tendo em vista o escopo da preocupaçăo na questăo econômica, começa entâo a promoçáo de mecanismos econômicos de proteçăo ao meio ambiente. Esta conferência também publicou um importante documento, denominado Agenda $21,{ }^{13} \mathrm{com}$ metas a serem cumpridas pelos Estados signatários (SILVA, 2009, pp. 31-35).

Esta predileçáo pelos mecanismos econômicos ficou muito evidente na discussâo que se intensificou na sequência desta conferência a respeito das mudanças

13 A Agenda 21 foi o tema principal do encontro do Rio, constituindo um documento para incluir medidas de vigilância e de avaliaçâo periódica para guiar os esforços da comunidade internacional no que se refere ao meio ambiente e desenvolvimento. O documento visava definir uma parceria entre diferentes atores na consolidaçăo do desenvolvimento sustentável (LE PRESTE, 2000, p. 221). 
climáticas, tanto em 1992 na Convençăo-Quadro das Naçóes Unidas sobre Mudança Climática, quanto em 1997, no Protocolo de Quioto, que estabelece limites para a reduçâo de gases de efeito estufa, que colaboram com a mudança do clima. ${ }^{14}$ Como parte do Protocolo, fez-se uma distinçăo de metas para países desenvolvidos e países em desenvolvimento (para năo prejudicar os mais pobres) e também foram instituídos mecanismos econômicos para facilitar o cumprimento dessas metas. Tais mecanismos, a exemplo dos mercados de carbono, possibilitam a negociaçấo de direitos de poluir por meio de mercados constituídos para esta finalidade. Inaugurase, portanto, a era da mercantilizaçăo da poluiçấo e, por consequência, da qualidade ambiental. Tais soluçôes, notadamente, advêm de uma racionalidade através da qual os problemas do mercado devem continuar a ser tratados unicamente pelo mercado, ignorando-se o fato de que este mesmo sistema econômico é quem gera o problema (MAMED, 2016). Vê-se, neste ponto, a contradiçăo mais atual vivenciada face à relaçâo entre sociedades e natureza.

A ideia de sustentabilidade tem sido utilizada em larga escala para justificar medidas mercadológicas. Nos anos que se seguiram à Rio 92, o discurso da sustentabilidade como equidade intergeracional é reforçada, quando se agrega a visăo de desenvolvimento sustentável enquanto a conciliaçăo dos vieses econômico, ambiental e social. Esta concepçáo foi efetivamente defendida neste período e plasmada na Cúpula Mundial para o Desenvolvimento Sustentável de 2002, na cidade de Joanesburgo. De acordo com Lago (2013, p. 118), o significativo crescimento econômico deste período, fez aumentar o padrâo de desenvolvimento ocidental, levando, obviamente, à percepçáo de uma inevitável dificuldade de implementar a ideia da sustentabilidade.

Posteriormente, em 2012, foi realizada a Conferência das Naçōes Unidas sobre Desenvolvimento Sustentável, conhecida também como Rio+20, em alusăo ao vigésimo aniversário da Rio 92. Além de resgatar os parâmetros de sustentabilidade já estabelecidos em conferências anteriores, a Rio+20 buscou consolidar uma nova e polêmica diretriz para a questăo ambiental, instituindo, assim, a ideia de economia verde. $\mathrm{O}$ conceito já vinha sendo trabalhado pelo Programa de Meio Ambiente das Naçôes Unidas (PNUMA) no âmbito da crise financeira de 2008, como um forte apelo de adaptaçấo de mercado e alternativa de crescimento econômico. A apresentação do conceito pelas Naçōes Unidas, no entanto, foi de certo modo imprecisa, parecendo uma reafirmaçấo da ideia de desenvolvimento sustentável. A instituiçăo internacional a denominou como: "aquela que resulta na melhoria do bem-estar humano e da igualdade social, ao mesmo tempo em que reduz significativamente os riscos ambientais e das limitac óes ecológicas" (PNUMA, 2015). Nâo obstante, nos documentos que tratam da efetivaçăo da economia verde encontram-se medidas como Mecanismos de Desenvolvimento Limpo, projetos de Reduçâo de Emissôes por Desmatamento e Degradaçăo Florestal (REDD) e outros instrumentos que buscam flexibilizar os limites de contaminaçâo ambiental, adequando as necessidades de reduçáo às demandas de mercado.

14 O fenômeno das mudanças climáticas passou a ser apontado pelo Painel Intergovernamental sobre Mudanças Climáticas em 1988 e consiste em que o planeta vem sofrendo, desde a Revoluçáo Industrial, um vertiginoso aumento em sua temperatura decorrente da emissăo de gases poluentes na atmosfera que causam o efeito estufa (aumento da temperatura pelo acúmulo desses gases). Como efeitos observados encontram-se o degelo de calotas polares, aumento no nível dos oceanos, submersăo das regiôes costeiras, perda de biodiversidade, aumento dos extremos climáticos, dentre outros (GIDDENS, 2010, pp. 29-40). 
Deste modo, repetidamente, os interesses econômicos săo sobrepostos às necessidades reais e urgentes de tratamento de uma crise ambiental sem precedentes na história. Ao invés de efetivamente ser incentivada a reduçăo das emissóes que se busca combater, vê-se a criaçăo de modelos pelos quais é possível compensar economicamente pela contaminaçăo realizada. No balanço de emissóes globais, deixar de exercer o 'direito a poluir' em um lugar, de modo algum compensa a poluiçăo que continua a ocorrer em outro. Talvez, por este motivo, os níveis de emissăo năo sejam reduzidos mesmo após a instituiçăo de tantos mecanismos. Nesse sentido, Marchesan (2003, p. 122) pondera que resta questionar a adoçâo de uma postura ambientalista oficial e a incorporaçấo de certas medidas governamentais e empresariais no que se refere à proteçăo do meio ambiente: trata-se da real necessidade de preservaçáo ambiental ou de mais um movimento em prol do interesse do mercado? De todos os dados históricos apresentados, vê-se como consenso que a exploraçăo desenfreada dos bens naturais constitui o principal motivo que levou ao nível de degradaçăo observado.

Na colonizaçáo, foram os discursos de inferiorizaçăo dos povos e a pressáo para sua desaculturaçăo que ditaram as regras para o aproveitamento econômico da natureza. Após a independência das colônias, o estigma de 'atraso' desses países. Atualmente, o discurso predominante remete à necessidade de melhoria da economia ao mesmo tempo em que se combata a crise ambiental proporcionada pelos modelos anteriores (MAMED, 2016).

Ou seja, como componente do pensamento ecológico atual, há que se considerar que há uma influência de alguns ciclos históricos que podem ser resumidos, grosso modo, como: a) o ideário de superaçăo do atraso pela tentativa de integrar-se na economia pela exploraçăo primária dos recursos naturais; b) Após séculos de exploraçâo, a influência que rege as questôes ambientais volta-se à identificaçăo e superaçăo dos problemas ambientais, cuja resposta advém de uma soluçâo inserida por um agente externo: primeiramente, as políticas preservacionistas, criadas em âmbito internacional e, após a verificaçăo de sua inviabilidade, as políticas de desenvolvimento sustentável; c) Visualizada a sua insuficiência, vê-se a criaçăo de novas e velhas soluçóes, sendo a mais atual a economia verde e sua ideologia de mercantilizaçấo da natureza (MAMED, 2016).

Assim, vê-se que a questăo ecológica atual ainda passa ao largo de tratar o tema pela maneira holística que necessita. Enquanto na Antiguidade e mesmo na Idade Média havia uma consideraçâo da natureza em aspectos mais amplos, a modernidade inaugurou uma profunda clivagem entre as sociedades e o meio que as rodeia, como se, separado, o meio devesse ser objetivado pelo ser humano, esquecendo-se a concepçăo sistêmica da vida. Como defende Capra (1996), a vida na terra é constituída por uma interligaçăo ecológica, em que todos os elementos săo interdependentes. Ideias como as de Capra, diante dos investimentos maciços do capital para propagar ideias mercadológicas, no entanto, acabam aparecendo em cenários muito restritos, vinculados à ideia de ecologia profunda (deep ecology) com divulgaçăo, por vezes, restrita ao âmbito acadêmico. À primeira vista, caberia um retorno às concepçōes mais holísticas sobre a natureza, deixando-se de pensar a questăo ambiental unicamente como um problema econômico. Esta postura (economicista) tem predominado desde que a temática ambiental adentrou com maior força às discussóes em distintos âmbitos da sociedade, sendo notável a influência nos discursos das conferências internacionais. Como 
resultado, tem-se observado apenas o agravamento da crise ambiental, de modo que resta clarividente a falência das medidas primordialmente econômicas para mitigar o problema.

Na análise da conformaçăo do pensamento ecológico atual, portanto, demonstra-se a presença de um ou outro elemento refletindo este histórico embate entre diferentes concepçóes de natureza ao longo da história, incluindo a persistente separaçâo entre humanidade e natureza. Desde a antiguidade, as sociedades debatem-se sobre sua condiçâo de parte indissociável, ou agente externo ao meio natural, oscilaçaáo observada ao longo da história e refletida nos modos de ser, fazer e viver das sociedades. No entanto, cabe observar quais aspectos úteis e necessários à relaçăo com a natureza foram perdidos e carecem de um resgate. Nas palavras de Bacon (1999, p. 45), é muito comum a humanidade incorrer em exageros, sendo necessário, portanto, estabelecer as preferências pela Antiguidade ou pelas coisas atuais:

Poucos săo os temperamentos que conseguem a justa medida, ou seja, năo desprezar o que é correto nos antigos, sem deixar de lado as contribuiçôes acertadas dos modernos. E é o que tem causado grandes danos tanto às ciências quanto à filosofia, pois faz-se o elogio da Antiguidade ou das coisas novas e năo o seu julgamento. (BACON, 1999, pp. 45-46)

Talvez haja chegado o momento em que a humanidade precise repensar o que deve resgatar do que se perdeu em tempos pretéritos. Entre os prejuízos inerentes à racionalidade moderna, esta separaçâo entre o humano e o natural, é preciso considerar que a humanidade sempre foi um ingrediente da natureza e năo apenas um elemento estranho a ela. É incontestável que a racionalidade moderna proporcionou um inédito incremento da qualidade de vida humana e do controle das adversidades da natureza, no entanto, como consequência, nâo há como ignorar os efeitos de degradaçấo do ambiente e mesmo as desigualdades sociais advindas desse modo de produzir que prioriza o mercado em detrimento das necessidades vitais humanas. Entre as inúmeras experiências e oportunidades trazidas pela modernidade, há que se comemorar os benefícios gerados, mas sem vendar os olhos para a consideraçâo das experiências degradantes, violentas e de desrespeito aos povos e ao ambiente. As experiências podem sempre servir ao aperfeiçoamento da vida em sociedade. Dessa breve análise de fundo histórica, filosófica e sociológica, vê-se a urgência do desafio em repensar um modelo de produçâo e consumo mais afeito às sociedades e à natureza.

\section{CONSIDERAÇÕES FINAIS}

Náo há como se pretender analisar o status quo das questóes ambientais atuais sem contextualizá-las em a gênese histórica das sociedades humanas e as ideologias que as sustentam. Tais análises săo complexas e demandam um esforço em termos de resgatar concepçóes de longa data que se repetem ao longo da história.

Da análise realizada, vê-se que o antigo dilema do ser humano de se incluir como parte da natureza ou como agente exterior a ela continua latente na contemporaneidade. A ideologia hegemônica contemporânea, além de dificultar a interpretaçáo da realidade, mostra-se também inibidora na busca de soluçôes da conflituosa relaçâo ser-humano e natureza. Os conflitos ambientais contemporâneos precisam ser 
interpretados à luz da organizaçăo social, política e econômica da sociedade humana. Talvez este possa ser um dos caminhos para enfrentar e discernir a crise ecológica da atualidade e buscar meios jurídicos para o estabelecimento de diretrizes que definirâo as políticas ambientais a serem adotadas.

A reflexăo proposta traz como contribuiçăo prática o despertar das ciências para a compreensâo da gênese do pensamento ambiental através da perspectiva histórica. Muito se fala da questăo ambiental e dos dilemas que esta impóe à sociedade, porém, comumente as análises se restringem a aspectos pontuais que năo contemplam a origem e história dos problemas. Deste modo, refletir sobre a questăo ambiental através do resgate do pensamento ecológico ao longo do percurso civilizatório ocidental é um esforço que certamente contribui para a compreensăo da atual crise civilizatória.

Do que fora contemplado na presente análise, observa-se que as sociedades antigas e mesmo as medievais, mantinham com a natureza um modo de produçăo muito específico, considerando-se como parte do sistema vivo e que deviam, portanto, compreendê-la para adequar-se frente aos desafios da época. A ruptura deste modo de perceber a natureza, no entanto, ocorreu com o advento da modernidade e do novo modelo econômico por ela inaugurado. Ao invés de pensar a economia enquanto modo de prover as necessidades humanas, passou-se a enxergá-las como uma infinita produtora de riquezas, gerando novas demandas de consumo, meios insustentáveis de produçăo e, portanto, produzindo um débito ambiental traduzido na conhecida crise ambiental. 0 domínio da natureza e o posicionamento do ser humano em separar-se dela, nesse sentido, parece expressar a perda que precisa ser resgatada no pensamento ecológico atual, especialmente, em tempos de ameaça à vida e à qualidade de vida, em todas as suas formas. 


\section{REFERÊNCIAS BIBLIOGRÁFICAS}

BACON, Francis. Novo organum: verdadeiras indicaçóes acerca da interpretaçăo da. natureza. Sâo Paulo: Nova Cultural, 1999.

BARROS, Carlos. La humanización de la naturaleza en la Edad Media. In: Revista História, Săo Paulo, v. 19, pp. 79-108., 2000.

BAZZANELLA, Sandro Luiz. A centralidade da vida em Nietzsche e Agamben frente à metafísica occidental e a biopolítica contemporânea. Tese. (Doutorado) Universidade Federal de Santa Catarina, Florianópolis, 2010.

BORNHEIM, Gerd. Os filosofos pré-socráticos. Săo Paulo: Cultrix, 1998.

BURSZTYN, Marcel; PERSEGONA, Marcelo. A grande transformaçăo ambiental: uma cronologia da dialética homem-natureza. Rio de Janeiro: Garamond, 2008.

CAPRA, Fritjof. A teia da vida: uma compreensăo científica dos sistemas vivos. Săo Paulo: Cultrix, 1996.

CARVALHO, Carlos Gomes de. Direito Ambiental: perspectivas no mundo contemporâneo. Revista de Direito Ambiental, n. 19, 2000.

COSTA Edimilson. A globalizaçăo e o capitalismo contemporâneo. Săo Paulo: Expressăo Popular, 2008.

CUNHA, Manoela Carneiro. Povos Tradicionais têm um pacto com o meio ambiente. Disponível em: <http://www.ispn.org.br/entrevista-com-manuela-carneiro-da- cunha/+povos+tradicionais+conceito\&cd =3\&hl =pt-BR\&ct=clnk\&gl=br>. Acesso em: 20 jul. 2010.

DA VINCI, Leonardo. Tratado de la pintura. Buenos Aires: Austral, 1947.

DESCARTES. Renée. 0 discurso do método. Sâo Paulo: Martins Fontes, 1996.

DIAMOND, Jared. Colapso: como as sociedades escolhem o fracasso ou o sucesso. 4. ed. Rio de Janeiro: Record, 2006.

ENGELS, Friedrich. A situaçăo da classe trabalhadora em Inglaterra. Porto: Afrontamento. 1975.

FEIJÓ, Ricardo. História do pensamento econômico. Săo Paulo: Atlas, 2001.

GIDDENS, Anthony. As consequências da modernidade. Săo Paulo: Editora UNESP, 1991.

HAYEK, Friedrich. 0 caminho da servidăo. 5. ed. Rio de Janeiro: Instituto Liberal, 1990.

KOIKE, Katsuzo. Aspectos da physis grega. Revista perspectiva filosófica. v. 6, n. 12, jul-dez, 1999.

LAGO, André Aranha Correa. Conferências de desenvolvimento sustentável. Brasília: Fundaçâo Alexandre Gusmâo, 2013.

LAS CASAS, Bartolomé. 0 paraíso destruído: a sangrenta história da conquista da América Espanhola. Porto Alegre: L\&PM, 2011.

LE PRESTE, Philippe. Ecopolítica internacional. Săo Paulo: SENAC, 2000. 
MAMED, D. O. Pagamentos por Servic, os Ambientais e mercantilizac, áo da natureza na sociedade moderna capitalista. 2016. (Tese de Doutorado) Pontifícia Universidade Católica, Curitiba, 2016.

MARCHESAN, Jairo. A questăo ambiental na produçăo agrícola: um estudo sócio-histórico-cultural no Município de Concórdia (SC). Ijuí: Unijuí, 2003.

MEIRINHOS, José Francisco; PULIDO, Manuel Lázaro. Pensar a natureza: problemas e respostas na Idade Média (Séculos IX-XIV). Porto: Faculdade de Letras da Universidade do Porto, 2011.

O'CONNOR, James. Causas naturales: ensayos de marxismo ecológico. México: Siglo XXI, 2001.

OST, François. A natureza à margem da lei. Lisboa: Piaget, 1995.

PÁDUA, José Augusto. Um sopro de destruiçăo: pensamento político e crítica ambiental no Brasil escravista (1786-1888). Rio de Janeiro: Jorge Zahar Editor, 2002.

PNUMA. Economia verde. Naçōes Unidas, 2013.

Disponível em: 〈http://www.unep.org.br/eventos_detalhar.php?id_eventos=39〉. Acesso em: 15 ago. 2015.

PRADO, Daniel Porciuncula. Facetas da práxis ambiental na antiguidade. Revista Biblios. Rio Grande: 14: pp. 7-14, 2002.

PRIGONINE, Illya e STENGERS, Isabelle. Nova Aliança: Metamorfose da ciência. Brasília: Editora Universidade de Brasília, 1991.

SANTOS, Theotonio. Revoluc,aào técnico-científica e capitalismo contempora`neo. Petrópolis: Vozes, 1983.

SEN, Amartya. Sobre ética e economia. Săo Paulo: Companhia das Letras, 1999.

SILVA, Solange Teles. 0 direito ambiental internacional. Belo Horizonte: Del Rey, 2009.

STEWART JUNIOR, Donald. O que é liberalismo. Rio de Janeiro: Instituto Liberal, 1995.

TERRY, Carmen Cristina e ÓRUE, Sonia. Consumo y producción sostenibles. Perspectivas. In: Producción y consume sostenibles: imperative de una estrategia de desarrollo económico. La Habana: Científico-Técnica, 2013.

VILLORO, Luis. El pensamiento moderno: filosofía del renacimiento. 2. ed. México: Fondo de Cultura Económica/ El Colegio Nacional, 2010.

RECEBIDO EM: 09/11/2016

APROVADO EM: 04/04/2017 